\title{
ARTYKUtY RECENZYJNE
}

Klio. Czasopismo poświęcone dziejom Polski i powszechnym PL ISSN 1643-8191, t. 47 (4)/2018, s. 203-218

\section{(c) $(1) \Theta$ \\ ADRIAN SZOPA \\ Granice cywilizacji, czyli postrzeganie barbarzyńców w późnym Cesarstwie Rzymskim}

\author{
Tomasz Skibiński SAC, Obraz barbarzyńców \\ w Cesarstwie Rzymskim w źródłach tacińskich \\ lat 376-476, Warszawa 2018, ss. 379
}

7 dużym zainteresowaniem odebrałem ukazanie się na rynku wydawnirzyńców przez Rzymian w burzliwym okresie ostatniego stulecia istnienia Cesarstwa Rzymskiego na Zachodzie. Mimo że temat ten jest niezwykle ciekawy i często pojawia się w literaturze przedmiotu, to jednak dla tego okresu badacze z reguły ograniczają się do szczegółowych studiów skoncentrowanych na twórczości jednego, czy grupy autorów lub też wybranym aspekcie zagadnienia ${ }^{1}$. Autor poszedł tutaj o krok dalej i choć jego praca

* Instytut Historii i Archiwistyki, Uniwersytet Pedagogiczny, ul. Podchorążych 2, 30-084 Kraków, aszopa@up.krakow.pl; ORCID: 0000-0001-7735-7145

${ }^{1}$ Zob. J. Gießauf, Barbares - Monster - Gottesgeißeln. Steppennomaden in europäischen Spiegel der Spätantike und des Mittelalters, Graz 2006; G. Halsall, Funny foreigners: laughing with the barbarians in late antiquity, [w:] Humour, History and Politics 
nie jest z pewnością pełnym opracowaniem tematu, to jednak niewątpliwie zawiera w sobie próbę syntetycznego spojrzenia na omawiane zagadnienie, już choćby $\mathrm{z}$ racji stuletniego horyzontu czasowego, w który wpisane są rozważania. Wybrany okres od 376 roku, czyli przekroczenia limesu dunajskiego przez Gotów, aż do 476 roku, czyli detronizacji uznawanego za ostatniego cesarza rzymskiego na Zachodzie Romulusa Augustulusa jest przede wszystkim symboliczny, ale daje się również uzasadnić merytorycznie. Jako materiał dla swoich rozważań Tomasz Skibiński przyjął dzieła tylko tych autorów, którzy żyli i tworzyli w tym czasie, w języku łacińskim. Bardzo duży wpływ na odbiór publikacji, do czego jeszcze wrócę, ma fakt, że autor uporządkował swoje źródła, a tym samym narrację, chronologicznie, na dalszy plan odkładając kwestie gatunkowe, stąd w poszczególnych

in Late Antiquity and the Early Middle Ages, red. G. Halsall, Cambridge 2002, s. 89-113; G.B. Ladner, On Roman Attitudes toward Barbarians in Late Antiquity, „Viator” 1976, 7, s. 1-26; R.W. Mathisen, Violent Behavior and the Construction of barbarian Identity in Late Antiquity, [w:] Violence in Late Antiquity. Perceptions and Practices, red. H.A. Drake, Aldershot-Burlington VT 2006; K. Smolak, 'Wer sind denn die schon?' Barbaren in satirischer Kleindichtung der Lateinischen Spätantike (zu Sulpicius Lupercus und Sidonius Apollinaris), [w:] Th. Haye - Franziska Schnoor, Epochen der Satire. Traditionslinien einer literarischen Gattung in Antike, Mittelalter und Renaissance, Hildesheim 2008, s. 35-54; F. Winkelmann, Die Bewertung der Barbaren in den Werken der oströmischen Kirchenhistoriker, [w:] Das Reich und die Barbaren, red. E.K. Chrysos and A. Schwarcz, Vienna 1989, s. 221-235.

Wspominane przez autora we wstępie prace: A. Chauvot, Opinions romaines face aux barbares au IVe siècle ap. J.-C., Paris 1998 oraz Y.A. Dauge, Le Barbare. Recherches sue la conception romaine de la barbarie et de la civilization, Bruxelles 1981 są w zasadzie jedynymi dużymi syntezami na ten temat. W literaturze anglo- czy niemieckojęzycznej, nie mówiąc już o polskiej, próżno szukać pozycji, które omawiałyby te kwestie bezpośrednio dla tego okresu i przybierały formę obszernego, syntetycznego studium. Osobno warto wspomnieć o szeroko analizującej zagadnienie, ciekawej pracy: E. Ohnacker, Spätantike und Frühmittelalterliche Entwicklung des Begriffs barbarus. Ein interdisziplinärer Versuch der Beschreibung distinktiver und integrativer gesellschaftlicher Konzepte, Münster-HamburgLondon 2003, która jest publikacją interdyscyplinarną, historyczno-socjologiczną. Sposób postrzegania barbarzyńców w sztuce Grecji i Rzymu aż do okresu późnej starożytności zob. I.M. Ferris, Enemies of Rome. Barbarians through Roman Eyes, Stroud 2000. Jest to pozycja bardzo ciekawa i wartościowa, chociaż zdecydowanie zbyt pobieżna jak na tak ambitne studium. 
rozdziałach znajdziemy przemieszaną literaturę historiograficzną, epideiktyczną, teologiczną czy też prawniczą.

Materiał uszeregowany został w sześć rozdziałów, każdorazowo wyznaczonych przez określone ramy chronologiczne ${ }^{2}$. W obrębie każdego z nich znajdują się podrozdziały, będące najczęściej omówieniem obrazu barbarzyńców $\mathrm{w}$ twórczości jednego $\mathrm{z}$ autorów antycznych, zaczynając od Ammiana Marcellina, a kończąc na Sydoniuszu Apolinarym³. Całość, zgodnie z prawidłami sztuki, poprzedza wstęp, w którym autor formułuje cel pracy i hipotezę badawczą, a także omawia aktualny stan badań oraz sygnalizuje źródła, z których zamierza skorzystać. Autor wyjaśnia również, dlaczego ogranicza się wyłącznie do źródeł łacińskich, pisząc: „Skupienie się wyłącznie na przekazach zachodniorzymskich - a więc łacińskich - jest podyktowane faktem, że w omawianym okresie wschodnia i zachodnia część Cesarstwa rozwijały się już zasadniczo niezależnie od siebie” (s. 22). Ta argumentacja jest moim zdaniem nietrafiona, zwłaszcza w odniesieniu do pierwszej części pracy. Przecież opisywane w rozdziale pierwszym wydarzenia w przeważającej mierze rozgrywały się na Wschodzie i nie dotyczy to tylko samej batalii pod Adrianopolem, ale i szeregu innych przytaczanych wydarzeń. We wstępie brakuje mi również pewnego bardzo ważnego doprecyzowania. Autor nie informuje czytelnika, kogo w swoich rozważaniach uważa za barbarzyńcę ${ }^{4}$. Czy koncentruje się tylko na tych miejscach, gdzie słowo barbarus padło expressis verbis, czy też uznaje tę kategorię za znacznie szerszą. Z samego tekstu trudno wyrokować na ten temat z całą pewnością, ponieważ można odnieść wrażenie, że za barbarzyńców sensu stricto uzna-

2 Jak pisze sam autor na stronie 26: „Układ rozdziałów uwzględnia przede wszystkim kryterium chronologiczne oraz pomocniczo kryterium środowiskowe i merytoryczne”.

3 Tę konsekwentną strukturę zaburza rozdział pierwszy, gdzie wydarzenia od wkroczenia Gotów w granicę imperium, aż do bitwy pod Adrianopolem, jakkolwiek opisywane na podstawie relacji Ammiana Marcellina, w spisie treści zostały wyodrębnione. Również omówienie źródeł prawniczych w rozdziale trzecim odbiega nieco od pozostałych.

${ }^{4}$ Jak nieostre może być to pojęcie, zob. znakomity artykuł: I. Wood, The Term 'barbarus' in Fifth-, Sixth-, and Seventh-Century Gaul, "Zeitschrift für Literaturwissenschaft und Linguistik" 2011, 41/4, s. 39-50. Zob. również P.J.Geary, Barbarians and Ethnicity, [w:] Interpreting Late Antiquity. Essays on the Postclassical World, red. G. W. Bowersock, P. Brown, O. Grabar, Cambridge MA - London 2001. 
wani są wyłącznie barbarzyńcy spoza limesu oraz ci, którzy stanowią grupę zdecydowanie odrębną od Rzymian, jak np. federaci w armii (czyli de facto ci, którzy spoza limesu przybyli). Z drugiej strony, autor uznaje Bessów czy Izauryjczyków za barbarzyńców, a przecież były to ludy, które - chociaż „o dzikiej naturze” - od setek lat mieszkały na terenie cesarstwa5 ${ }^{5}$. Co wreszcie zrobić z Persami? ${ }^{6}$ Są to pytania ważne i próba odpowiedzi na nie byłaby w pracy bardzo pożądana ${ }^{7}$. Niestety, próżno szukać pogłębionej refleksji na ten temat, a termin barbarzyńca omówiony jest bardzo pobieżnie na dwóch stronach ${ }^{8}$. Do tego niestety przy rozważaniach etymologicznych wkradła się jeszcze na stronie 18 niefortunna literówka, gdzie w przypisie 3

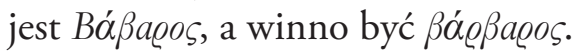

W rozdziale pierwszym autor koncentruje się na okresie od przekroczenia przez Gotów Dunaju aż do śmierci Teodozjusza I. W swoich rozważaniach opiera się głównie na relacji Ammiana Marcellina i dotyczy to zarówno podrozdziału pierwszego, jak i początku drugiego. Ten ostatni uzupełnia trzech autorów: Symmach, Wegecjusz oraz anonimowy autor Epitome de Caesaribus. Jakkolwiek chronologicznie zbieżne, teksty przywoływanych autorów są całkowicie odmienne gatunkowo. Także ich osobiste

${ }^{5}$ Bessowie, plemię trackie, którzy przywoływani są na stronie 122, określani są w przywoływanych źródłach jako duri, a ich „barbarzyńskość” jest raczej historyczna niż aktualna - Rzymianom dali się we znaki w I w. p.n.e., stawiając im długotrwały opór. Dzikość Traków była toposem już od czasów Homera. Na s. 124 autor sam zaznacza, że „chodzi tutaj o barbarzyńców „wewnętrznych”, a więc o ludy przynależące do Cesarstwa, ale żyjące na jego obrzeżach i słabo zromanizowane". Na temat tych drugich sam autor na s. 53 w przyp. 92 zauważa, że Ammian nazywa ich latrones, a nie barbari. Por. K. Feld, Barbarische Bürger. Die Isaurier und das Römische Reich, Berlin - New York 2005.

${ }^{6}$ Por. S. McDonough, Where Sasanians Barbarians? Roman Writers on the 'Empire of the Persians', [w:] Romans, Barbarians and the Transformation of the Roman World. Cultural Interaction and the Creation of Identity in Late Antiquity, red. R. Mathisen, D. Shanzer, Farnham-Burlington VT 2011.

${ }^{7} \mathrm{Na}$ temat ewolucji pojęcia barbarzyńca zob. np. D. Timpe, Der Barbar als Nachbar, [w:] Ideologie - Sport - Außenseiter. Aktuelle Aspekte einer Beschäftigung mit der antiken Gesellschaft, red. C. Ulf, Innsbruck 2000, s. 203-230.

${ }^{8}$ Nie oczekuję oczywiście od autora w tym miejscu pełnego omówienia tego szerokiego tematu - nie jest to przedmiot jego pracy. Uważam jednak zasygnalizowanie współczesnych trendów żywiołowej dyskusji naukowej wokół tych zagadnień za potrzebne i wartościowe. 
doświadczenia oraz motywy, jakimi kierowali się przy konstruowaniu narracji, są zupełnie różne. $Z$ jednej strony prowadzi to $\mathrm{w}$ pewnym stopniu do konsternacji czytelnika, który może mieć kłopoty z określeniem, kim w końcu ów omawiany barbarzyńca jest. Wykreowany przez Symmacha obraz barbarzyńcy nie jest zbieżny z tym, który znajdujemy przykładowo u Wegecjusza. Jeżeli do tego dodamy Izauryjczyków z opisu Ammiana, to odpowiedź na pytanie o definicję barbarzyńcy jeszcze bardziej się oddala. $\mathrm{Z}$ drugiej strony, takie przedstawienie tych zagadnień pokazuje, jak skomplikowana była to materia i jak trudno o jej jednoznaczne uściślenie.

W omawianym rozdziale autor porusza jeszcze dwie ważne i dyskutowane kwestie. Podkreśla (nie tylko w tym miejscu) daleko posunięty proces barbaryzacji armii oraz fakt, że - jak możemy przeczytać na stronie 74: „...połączenie sił barbarzyńskich i rzymskich w jednej armii było tylko powierzchowne i nie dokonała się integracja wojsk pochodzenia barbarzyńskiego z Rzymianami, a podział był zapewne dużo głębszy niż tylko wyznaczony przez odrębny strój”. Twierdzenie to jest co najmniej kontrowersyjne? ${ }^{9}$. Oczywiście nikt nie przeczy, że w omawianym w książce okresie barbarzyńcy w armii rzymskiej byli i osiągali nawet wysokie stanowiska, jednak już ich ilość oraz stopień integracji wymaga z pewnością znacznie dokładniejszego komentarza ${ }^{10}$. Konstatacja ta wydaje się tym bardziej niepokojąca, że następuje jako interpretacja fragmentu Epitome de Caesaribus na temat poufałej relacji pomiędzy cesarzem Gracjanem a towarzyszącymi mu jako przyboczni Alanami ${ }^{11}$. Wydaje się, że takie wnioskowanie jest nadmiernym uproszczeniem.

W rozdziale drugim autor zajmuje się tekstami autorów chrześcijańskich. Powołuje się tu na opinie o barbarzyńcach Ambrożego z Mediolanu, Chromacjusza z Akwilei, Rufina z Akwilei, Sulpicjusza Sewera, Paulina z Noli, Maksyma z Turynu oraz Prudencjusza. Jest to niezwykle ciekawy

9 Jako pewnik funkcjonuje raczej w starszej literaturze. Zob. np. R. MacMullen, Corruption and the Decline of Rome, London 1988, s. 176.

${ }_{10}$ Por. H. Elton, Warfare in Roman Europe, AD 350-425, Oxford 1997, s. 136 i n. oraz 272-277.

11 Już u wcześniejszych władców, poczynając od samego Augusta, znajdujemy przybocznych barbarzyńskiego pochodzenia, co jednak nie świadczy o barbaryzacji armii rzymskiej w I wieku. 
fragment pracy i widać wyraźnie znakomite obeznanie autora w tego typu literaturze. Pokazuje on, jak pryzmat religii może przekształcać sposób patrzenia na barbarzyńców i, bardziej abstrakcyjnie, „barbarzyństwo”. Nacechowane pejoratywnie ostrze tego pojęcia pozwala się stępić dzięki wierze chrześcijańskiej. Już nawet przybysze spoza imperium, jeżeli ochrzczeni, zasługują na „zaproszenie do wspólnoty prawdziwej wiary” (s. 93). Autorzy chrześcijańscy nie przestali dostrzegać zagrożeń oraz strat, jakie dla cesarstwa przyniosły najazdy barbarzyńskie. Uważają jednak, że chrześcijaństwo pozwala zwalczyć pierwotną dzikość, jaką odznaczają się przybysze, co umożliwia pokojowe współżycie w nowej rzeczywistości, budowanej na gruncie słynnej opinii wyrażonej przez św. Pawła w 3 rozdziale listu do Galatów ${ }^{12}$. Warto podkreślić, że autorzy solidarnie przemilczają fakt ariańskiego wyznania większości barbarzyńców, wychodząc być może z założenia, że wyrozumiałe potraktowanie tej słabości pozwoli w przyszłości naprowadzić ich na drogę ortodoksji ${ }^{13}$.

Rozdział trzeci składa się z dwóch bardzo różniących się od siebie podrozdziałów. W pierwszym z nich, na dziesięciu stronach, autor analizuje ustawodawstwo rzymskie wobec barbarzyńców. Prezentuje tutaj bardzo ciekawe spostrzeżenia na temat użycia słowa barbarus w terminologii prawniczej i dotyka tych sfer, w których barbarzyńcy wkraczali w zasięg zainteresowań prawa rzymskiego. Rozważania te są bardzo interesujące. Autor powołuje się tutaj na Kodeks Teodozjański oraz Kodeks Justyniański. Choć tylko jeden z nich powstał w okresie, do którego ogranicza się praca, to precyzyjne datowanie poszczególnych przepisów w zbiorach pozwala na włączenie w zakres rozważań również drugiego, chociaż został on sporządzony w VI wieku, więc teoretycznie nie spełnia kryterium chronologicznego. Wprowadzenie źródeł normatywnych znakomicie poszerza zakres rozważań oraz pogłębia samą refleksję na temat barbarzyńców, jednak równocześnie jeszcze mocniej komplikuje kwestie interpretacyjne, a w zestawieniu

12 Ga. 3, 28.

13 Wartościową pozycją, która wzbogaciłaby rozważania autora na ten temat, jest monografia zbiorowa Arianism. Roman Heresy and Barbarian Creed, red. G.M. Berndt, R. Steinacher, Farnham UK and Burlington VT, 2014. 
z typami źródeł przywoływanymi we wcześniejszych rozdziałach potęguje odczucie nieporównywalności.

Wrażenie to wzmacnia fakt, że w następnym podrozdziale zostajemy przeniesieni do całkowicie innego świata - literatury popisowej. Autor tytułuje tę część „Piewcy wielkości Rzymu” i zawiera w niej rozważania na temat dzieł Klaudiusza Klaudiana (nie wiem czemu określanego tutaj jako „Klaudian Klaudiusz”), Rutyliusza Klaudiusza Namacjanusa oraz Flawiusza Merobaudesa. Wkraczając w świat literatury panegirycznej, gatunkowo bardzo specyficzny, mocno zakorzeniony w tradycji literackiej, przepełniony aluzjami, wielowarstwowy, zmuszeni jesteśmy do niezwykle ostrożnego poruszania się po nim, a proste wnioskowania mogą prowadzić do nieporozumień. Mam niestety wrażenie, że tak właśnie stało się w tym przypadku. Swój punkt widzenia pozwolę sobie przedstawić na podstawie fragmentu dotyczącego Klaudiana. Na s. 154 autor stwierdza: „opinia poety o barbarzyńcach...”. Zdaję sobie sprawę, że prawdopodobnie użyty został tutaj skrót myślowy, jednak bardzo dobrze oddaje zastrzeżenie, które chciałbym poczynić. Panegiryk nie jest żadną „opinią poety”. To utwór całkowicie, przynajmniej już w tym okresie, podporządkowany doraźnemu celowi, najczęściej politycznemu. Autor na kolejnych stronach próbuje pokazać ewolucję postrzegania barbarzyńców przez Klaudiana jak możemy przeczytać „od wrogości... przez akceptację... do wrogości”. Jeżeli chcielibyśmy brać tekst panegiryku jako osobistą opinię poety, świadczyłoby to o dużej fluktuacji jego poglądów. Nie można zapomnieć również, kto był mocodawcą Klaudiana. Flawiusz Stylichon nie tylko był półkrwi barbarzyńcą, ale również jego polityka wobec przybyszów była bardzo odważna i liberalna. Nie mogę się zatem zgodzić z takimi wnioskami jak np. ten ze s. 155, że tekst panegiryku „...jest świadectwem wzrastającego optymizmu i otwartości...” poety, albo ze s. 162 , że „...jest już bardzo daleki nie tylko od myśli o integracji i przyszłych obywatelach rzymskich pochodzących z ludów barbarzyńskich...”. Panegiryki pisane w kontekście walk z Alarykiem musiały mieć wydźwięk antybarbarzyński. Możemy być przekonani, że jeżeli sytuacja polityczna uległaby zmianie, to i odbicie tego stanu rzeczy natychmiast znaleźlibyśmy na kartach panegiryków. Podobnych wniosków mamy niestety więcej. Fragment inwektywy (a zatem przeciwieństwa panegiryku, które rządziło się mutatis mutandis 
tymi samymi regułami) In Eutropium ma wskazywać „przemiany, jakie zachodziły w barbarzyńcach porzucających plemienne zwyczaje” (s. 156). Z kolei bunt Trybigilda jest przedstawiony jako „regres w postępie cywilizacyjnym i romanizacji” (s. 156). Tak proste interpretacje są niestety w tej sytuacji niedopuszczalne. Nie są to jedyne przykłady. Brakuje szerszego komentarza. Trudno mi uwierzyć, że autor w całej rozciągłości bierze za dobrą monetę wywody Klaudiana, jednak nawet jeżeli tak nie jest, to nie daje na to wyraźnych dowodów w toku narracji. W podsumowaniu podrozdziału możemy odnaleźć konstatację, że „Cały obraz barbarzyńców u Klaudiana jest wieloaspektowy, zależny od zewnętrznych wydarzeń oraz uwarunkowany rodzajem i celem dzieł" (s. 163), ale to słuszne spostrzeżenie nie znajduje żadnego przełożenia na pojawiające się wnioski, które są po prostu błędne $e^{14}$.

Rozdział IV koncentruje się ponownie na utworach autorów chrześcijańskich. W pierwszym podrozdziale omówiona zostaje różnorodna twórczość Hieronima ze Strydonu oraz krótko utwór poetycki Commonitorium Oriencjusza. Drugi podrozdział poświęcony jest kronikarstwu historycznemu, a dokładnie trzem ważnym kronikom: galijskiej, Prospera z Akwitanii oraz Hydacjusza. Szczególnie wartościowy jest tutaj obszerny fragment poświęcony Hieronimowi. Autor analizuje z dużym znawstwem liczne jego dzieła, oferując do nich wartościowy komentarz ${ }^{15}$. Jeden z przywoływanych tekstów - List 106 na temat tłumaczenia księgi psalmów - chyba najdobitniej pokazuje, że sporo przywołanych utworów bardzo niewiele mówi nam faktycznie o postrzeganiu barbarzyńców w tamtych czasach. We wspomnianym liście autor widzi w chrystianizacji Gotów „realizację proroctw o czasach mesjańskich” (s. 197), a ich obraz ma być nie tyle odbiciem rzeczywistości, co biblijnych proroctw i jest niczym innym jak tylko środkiem literackim.

${ }_{14}$ Mowa na przykład o końcowym stwierdzeniu podsumowującym, że: „Klaudian [...] jest przede wszystkim świadkiem wydarzeń, a swoje zadanie odczytywał jako przedstawienie faktów, a nie wywieranie na nie wpływu”. Jeśli istotnie by tak było, to ten cel zdecydowanie bardziej spełniałaby historiografia, a nie literatura panegiryczna.

15 Wydaje się, że na stronie $190 \mathrm{w}$ przyp. 32 po raz pierwszy odnajdujemy tak jasno wyrażoną opinię, że taki, a nie inny obraz barbarzyńców służył konkretnemu celowi i był przez niego determinowany. 
Z kolei podrozdział poświęcony kronikom stanowi dowód na to, jak duże korzyści mogłoby przynieść zastosowanie kryterium genologicznego przy omawianiu prezentowanego w pracy korpusu dzieł. Ponieważ autor przedstawia trzy duże dzieła tego samego gatunku, stara się to uczynić według jednego klucza: słownictwo, opisy walk, układy itp. Dzięki temu układ podrozdziału jest klarowny, a zestawienie porównywalnych narracji prowadzi do ciekawych wniosków.

Niezwykle interesująco rozpoczyna się rozdział $\mathrm{V}$, od szerokiego omówienia bogatej spuścizny literackiej św. Augustyna. Dalsze rozważania są nie mniej zajmujące, ponieważ zwierają treści przekazane nam między innymi przez Orozjusza oraz Salwiana z Marsylii. Podrozdział ten uzupełnia pisarstwo Possydiusza oraz Quodvultdeusa z Kartaginy. Spektrum postaw wobec barbarzyńców zaprezentowane w tym rozdziale jest niezwykle szerokie. Chociaż ponownie mamy do czynienie z korpusem dzieł bardzo trudnych do porównywania, to jednak wydaje się, że pewien wspólny mianownik udało się autorowi odnaleźć. Wspomniani pisarze chrześcijańscy starają się ułagodzić wizerunek barbarzyńskich najeźdźców i czynią to na różnorodne sposoby, co zostało tutaj atrakcyjnie zaprezentowane. Ponownie pewien niedosyt budzi we mnie kwestia komentarza do tekstu. Przykładowo słynny fragment z Orozjusza, w którym opisywana jest procesja z naczyniami liturgicznymi do kościoła św. Piotra w Rzymie, został skomentowany w kilku zdaniach. Wydaje się, że wobec tak atrakcyjnego materiału można było pokusić się o szersze rozważania. Ich lektura byłaby z pewnością nie tylko bardzo pouczająca, ale i przyjemna. Czy możemy oczekiwać, że mieszkańcy plądrowanego przez Gotów Rzymu podzielali opinie Orozjusza? Z całą pewnością nie. Pisarz ten miał dla swoich rozważań konkretny cel i stąd takie, a nie inne przedstawienie najeźdźców, których obraz możemy niewątpliwie uznać za zakłamany.

Rozdział ostatni, dotyczący chronologicznie ostatniego ćwierćwiecza istnienia zachodniej części cesarstwa, koncentruje się na spuściźnie piśmienniczej trzech wielkich autorów: Leona Wielkiego, Paulina z Pelli oraz Sydoniusza Apollinarisa. Chociaż każdy z nich był autorem chrześcijańskim, a dwóch nawet osobami duchownymi, to jednak pozostawione materiały (ponownie) bardzo różnią się od siebie. Podrozdział poświęco- 
ny pierwszemu z autorów zawiera bardzo nieliczne wzmianki na temat samych barbarzyńców. Znacznie ciekawszy jest fragment koncentrujący się wokół utworu Eucharisticos Paulina z Pelli. Przedstawia on opis wydarzeń sprzed wielu lat pisany z perspektywy starca podsumowującego swoje życie. Ponieważ był on świadkiem opisywanych wydarzeń, które w sposób bezpośredni wpłynęły na jego życie, relacja ta, mimo dystansu czasowego, jest bardzo osobista, żywa i z pewnością wiarygodna. Paulin stara się niuansować postawy barbarzyńców i dzieli się z czytelnikiem swoimi cennymi refleksjami na ten temat.

Rozdział zamyka bogata spuścizna Sydoniusza Apollinarisa, składająca się z jego listów oraz utworów panegirycznych. Zwłaszcza te pierwsze dzieła są kopalnią wiedzy na temat sytuacji w Galii u schyłku panowania rzymskiego, w tym tego, jak postrzegani byli barbarzyńcy. Autor przedstawia niezwykle barwne fragmenty dotyczące barbarzyńców, z których wyłania się dość stereotypowy obraz. Musimy jednak pamiętać, że przedstawiany punkt widzenia należał do rzymskiego arystokraty, człowieka wysokiej kultury, a także to, że epistolografia antyczna, jako gatunek literacki, znacznie różniła się od jej dzisiejszej formy. Nie ma powodu, żeby wątpić w pogardliwy stosunek Sydoniusza do barbarzyńców, jednak jest on również elementem kształtowania wizerunku własnej osoby i nie wolno o tym zapominać. Przedstawienie barbarzyńców wyłącznie jako „prymitywnych i brudnych”, bo tak pisze o nich najczęściej Sydoniusz, przypomina naigrawanie się intelektualisty z osób nieokrzesanych, ale dysponujących większą od niego władzą i jest przewidziane jako szyderstwo, skierowane do uszu ludzi jemu podobnych. Wydaje się, że pochodzenie etniczne ma tu drugorzędne znaczenie. Opinie Sydoniusza miały zapewne jakieś pokrycie w faktach, ale znacznie więcej w nich kliszy, przez wieku kreowanego stereotypu. Czasami jest on tak silny, że budzi podejrzenie, czy nie mamy tu do czynienia z konwencją literacką. Przykładowo, obraz Hunów, który wyłania się z jego tekstów, komentowanych przez autora na stronach 325-326, niewiele różni się od tego, który niemal sto lat wcześniej przedstawił Ammian Marcellin. Jeżeli porównamy go przykładowo z wiarygodną relacją Priskosa, z mniej więcej tego samego okresu, to zobaczymy, jak ostrożnym należy być z oceną wia- 
rygodności kreowanego wizerunku ${ }^{16}$. $Z$ jeszcze większą rezerwą należy podchodzić do panegiryków. Zastrzeżenia, które przywołałem powyżej przy okazji Klaudiana, pozostają aktualne. Ukształtowany w nich wizerunek barbarzyńców jest nacechowany wyraźnie negatywnie, poza tymi sytuacjami, kiedy bieżąca sytuacja polityczna wymagała zdecydowanej wolty. Obrazuje to znakomicie fragment panegiryku na cesarza Majoriana, w którym pojawia się postać potężnego magistra militum Rycymera. Powodem do dumy staje się nie tylko to, że jest on barbarzyńcą, ale to, że niejako podwójnym, z ojca Sweba i matki Wizygotki ${ }^{17}$. Czy możemy na tej podstawie wywnioskować szczególnie życzliwą postawę Sydoniusza na temat tych dwóch plemion?

Narrację zamyka zakończenie, które jest podsumowaniem dotychczasowych rozważań, oraz bibliografia i streszczenie w języku angielskim. $\mathrm{Na}$ stronie 344 możemy przeczytać konkluzję: „W rzymskiej narracji o barbarzyńcach jest widoczna istotna przemiana postrzegania relacji rzymsko-barbarzyńskich i miejsca barbarzyńców w Cesarstwie, jaka dokonała się w okresie objętym badaniami” (s. 344) i jest ona bardzo trafna. Pod wpływem zmieniających się realiów autorzy rzymscy zmuszeni byli zweryfikować swój punkt widzenia. Otwarcie pogardliwy i lekceważący stosunek do przybyszów, niezdolnych wstrząsnąć najgłębszymi fundamentami państwa rzymskiego, z czasem nie pozwalał się obronić. Bliższe

16 Priscos Panites 11.2.356-387 (opis siedziby Attyli oraz strojów Hunów) oraz 13.1.19-83 (opis uczty u Hunów), wyd. Priscus, Fragments, red. R.C. Blockley, The Fragmentary classicising Historians of the Later Roman Empire: Eunapius, Olympiodorus, Priscus and Malchus, t. II, Liverpool 1983, s. 223-400. Przekład polski części tekstu: J. Kuranc, Wyprawa poselstwa wschodniorzymskiego na dwór Attyli, „Meander” 1957, 12, s. 20-36.

17 Sidonius Apollinaris, carm. II, w. 360-362: tum livet quod Ricimerem/in regnum duo regna vocant; nam patre Suebus, /a genetrice Getes (wyd. Panegyrici et carmina, [w:] Sidoine Apollinaire, Poèmes, red. A. Loyen, Paris 1960. Przekład polski: M. Brożek, Sydoniusz Apolinary. Listy i wiersze, Kraków 2004). Aby być precyzyjnym, należy podkreślić, że faktycznie to nie samo bycie barbarzyńcą, ale królewskie pochodzenie jest wychwalane w panegiryku. Rycymer jest tutaj postawiony antytetycznie w stosunku do Gejzeryka, którego korzenie nie były tak szlachetne. Nie zmienia to jednak faktu, że barbarzyńska krew nie jest dla panegirysty żadnym obciążeniem, a pochodzenie od szlachetnego Sweba i dobrze urodzonej Wizygotki jest atutem i powodem do dumy. 
i częstsze kontakty pomiędzy Rzymianami i barbarzyńcami w życiu codziennym musiały wpływać na wzajemne relacje i generować zupełnie nowe, niespotykane wcześniej sytuacje. Znajduje to odbicie w źródłach, w których nie słyszymy już wyłącznie o dzikich najeźdźcach zza Renu czy Dunaju, ale pojawiają się obrazy nowe, dotąd nieoglądane. Czy jednak możemy powiedzieć, że wraz z upływem czasu zmienia się zasadniczo wizerunek samych barbarzyńców? I tak, i nie. Zależy to w dużej mierze od gatunku literackiego i wymaga każdorazowo pogłębionej refleksji. Przedstawianie ich jako dzikich najeźdźców jest równie powszechne na początku, jak i na końcu analizowanego okresu. Oczywiście, pojawiają się nowe warianty, jednak wszelkie zdecydowane odchylenia od stereotypu związane są nie z upływem czasu, ale doraźnym celem piszącego oraz aktualnie panującą sytuacją. Sam autor zresztą zauważa: „W konsekwencji odbicie w źródłach znajdowała zarówno sytuacja polityczna, jak i związane z nią działania i postawy barbarzyńców, a niekiedy także doświadczenia osobiste autorów. To one wpływały na postrzeganie barbarzyńców i były istotnym kryterium zmienności i wieloaspektowości przedstawianego obrazu” (s. 345). Jest to trafna uwaga, jednak stawia pod znakiem zapytania ideę chronologicznego zestawienia materiału. Wydaje się, że by prześledzić proces zmiany wizerunku barbarzyńcy w źródłach, należało konsekwentnie analizować je według określonego klucza, tak jak gdzieniegdzie autor próbuje to robić w mniejszej skali. Tymczasem otrzymujemy bogaty zbiór różnorodnych i niezwykle ciekawych obrazów, który pokazuje bogactwo form w tej materii, ale już nie tak wyraźnie ich ewolucję w czasie, a to było zasadnicze zamierzenie autora, które sformułował w swojej hipotezie badawczej (s. 24). Brakuje mi szerszej, syntetycznej refleksji, która mogłaby podsumować przywołany materiał i uzasadnić takie, a nie inne jego zaszeregowanie. W tym dostrzegam największy mankament tej, skądinąd bardzo ciekawej, publikacji.

Trudno również jest mi zgodzić się $\mathrm{z}$ inną opinią autora, którą przytacza na stronie 345: „...podział na Rzymian i barbarzyńców jest w świetle źródeł z okresu 376-476 - jasny...”. Nawet wyłączna lektura pracy zdaje się sugerować coś innego. Zdecydowanie kimś innym jest barbarzyńca dla Symmacha, innym dla Ambrożego, a jeszcze innym dla Salwiana. Symmachowe quis ita familiaris est barbaris, ut aram Victoriae 
non requierat było dla Ambrożego niedorzeczne, a dla Salwiana już obce ${ }^{18}$. Autor nie odpowiada jednoznacznie na pytanie, kto był barbarzyńcą, a kto nie, być może dlatego, że w interesującym nas okresie odpowiedź na nie jest bardzo trudna, jeżeli nie niemożliwa - zależy ona bowiem od punktu widzenia, a ten mógł być bardzo różny. Można jednak żałować, że na podstawie tak bogatej i szerokiej analizy autor nie pokusił się jednak o rozważania na ten temat. $\mathrm{Z}$ pewnością mógłby wiele ciekawego $\mathrm{w}$ tej sprawie napisać.

Wypada również wspomnieć, że w przeważającej części książka wolna jest od literówek, drobnych błędów czy lapsusów językowych ${ }^{19}$. Poniżej przytoczę jedynie kilka uwag, które być może przydadzą się do ewentualnego drugiego wydania. Dowódca Ammiana Marcellina (s. 30) to Ursycyn, a nie „Ursacyn”. Słowo largitio w języku łacińskim jest rodzaju żeńskiego, a zatem winno być comes sacrarum largitionum a nie sacrorum (s. 66, 72). Przywoływany na stronie 66 (również w bibliografii) polski badacz to J. Wiewiorowski, a nie J. Wiewiórkowski. Dziwny błąd wkradł się również w słowie foederati, które w różnych miejscach (np. s. 208, ale nie tylko) pisane jest jako feoderati. Inną kwestią, którą autor mógłby jeszcze raz przemyśleć, jest - wzbudzające wciąż żywe dyskusje polskich badaczy - polonizowanie imion starożytnych oraz urzędów i rang. W publikacji przyjęta została zasada spolszczania, w której jednak możemy odnaleźć sporadycznie niekonsekwencje. Przykładowo czytamy o Profuturze czy Alateuszu, ale już o Lupicynusie (s. 42), a nie Lupicynie, czy Themistiosie (s. 163), a nie Temistiuszu. Dziwi też wspomnienie o bitwie pod Pollentią (s. 161), a nie Polencją. W języku polskim łacińska Sapaudia (s. 208, 333) to raczej dźwięczna Sabaudia. Sugerowałbym również większą konsekwencję oraz ponowną refleksję nad zapisywaniem rang i urzędów

${ }^{18}$ Symmachus, Relatio 3,3. (wyd. Quintus Aurelius Symmachus, Relationes, red. O. Seeck, MGH AA 6.1, Berolini 1883, s. 279-317).

19 Wspomniane błędy drobne to: s. 22 zamiast „liturgii i z języka” winno być „liturgii z języka”, oraz „Arkadiusz na Wschodnie” na „Arkadiusz na Wschodzie”; s. 161 zamiast „dzieje” winno być „dziele”; s. 218 zamiast truculentissums” winno być „truculentissimus”; s. 225 zamiast Richard w. Burgess” winno być „Richard W. Burgess”; w spisie treści podrozdział „Rutyliusz Klaudiusz Namacjanus” widnieje pod stroną 165, podczas gdy w tekście jest to strona 163. 
późnoantycznych. Swoje wątpliwości przedstawię na podstawie dwóch wysokich urzędów: głównodowodzącego wojsk (magister militum) oraz prefekta pretorium (praefectus praetorio). Na s. 161 możemy przeczytać: „...zgłaszane zastrzeżenia do takich uprawnień magister militum...”, jednak już w przypisie 97 na ten sam temat widnieje: „...w zakres kompetencji prefekta, a nie magistra militum”. Na s. 147: „... skierowana do prefekta pretorio Teodora...”. Jak widać, wkradło się tu nieco nieścisłości, którym należy się przyjrzeć. Zmierzając do konkluzji, pragnę wreszcie wskazać na kilka publikacji, które mogłyby być wartościowe w kontekście niniejszej pracy, oraz jeden dotkliwy brak. Za taki uważam zdecydowanie nieobecność wśród źródeł De origine et situ Germanorum Publiusza Korneliusza Tacyta. Ukształtowany przez dziejopisa obraz barbarzyńców miał niezwykle silne oddziaływanie i pomimo kilku wieków, jakie minęły od czasu napisania tego dzieła, niewiele stracił on na aktualności. Wnikliwa analiza mogłaby pokazać, że zwłaszcza w tych źródłach, które gatunkowo były bardzo konserwatywne, przedstawiony przez autorów obraz niewiele zmienił się od czasu wczesnego cesarstwa oraz to, jak wiele w przywoływanych tekstach jest opinii wtórnych, stereotypowych, bazujących na utrwalonym przez wieki w literaturze rzymskiej toposie. $Z$ tego właśnie powodu uważam pominięcie dzieła Tacyta za spore uchybienie. W zakresie współczesnej literatury można dostrzec pewne niedoszacowanie prac niemieckojęzycznych (widać wyraźnie francusko-włoskie preferencje autora, co oczywiście w żadnym razie nie powinno być odczytane jako zarzut), choć należy oddać, że większość najważniejszych publikacji została uwzględniona. Wartościowe uzupełnienie stanowiłyby z pewnością liczne artykuły zawarte w Das Reich und die Barbaren pod redakcją Evangelosa Chrysosa oraz Andreasa Schwarcza ${ }^{20}$, czy też rozważania Philippa von Rummela dotyczące strojów, na który to aspekt autor wielokrotnie zwraca uwagę ${ }^{21}$. W pogłębieniu refleksji na temat zawartości przywoływanych w narracji panegiryków mogłaby pomóc monografia

20 Das Reich und die Barbaren, red. E. Chrystos, A. Schwarcz, Wien-Köln 1989.

${ }^{21}$ Ph. von Rummel, Habitus barbarus. Kleidung und Repräsentation spätantiker Eliten im. 4. und 5. Jahrhundert, Berlin - New York 2007. 
Claudii Schindler ${ }^{22}$. Również ważna praca Romans, Barbarians, and the Transformation of the Roman World. Cultural Interaction and the Creation of Identity in Late Antiquity pod redakcją Ralpha Mathisena oraz Danuty Shanzer winna była znaleźć się w bibliografii ${ }^{23}$. Szczególnie jej pierwszy rozdział zatytułowany Literary Constuctions of Barbarian Identity mógłby pogłębić refleksję autora na temat niektórych zagadnień przestawionych w źródłach. O wielu zagadnieniach związanych z procesem integracji barbarzyńców w społeczeństwie rzymskim traktuje ważny zbiór cennych artykułów pod redakcją Waltera Pohla zatytułowany Kingdoms of the Empire. The Integration of Barbarians in Late Antiquity ${ }^{24}$. Myślę, że pewna zmianę w sposobie interpretacji niektórych fragmentów źródłowych mogłaby wywołać lektura artykułu wspomnianego przed momentem Waltera Pohla pod tytutem Perceptions of Barbarian Violence ${ }^{25}$. Nie chodzi tu oczywiście o wskazywanie wszystkich prac, jakie jeszcze można byłoby włączyć do rozważań, ale wydaje mi się, że tych kilka wyżej wymienionych mogłoby szczególnie wzbogacić refleksje autora.

Książkę Tomasza Skibińskiego czyta się z przyjemnością, a przytaczane przez niego różnorodne wizerunki barbarzyńców wzbogacają wiedzę czytelnika o niezwykle ciekawej epoce późnej starożytności. Ma ona pewne braki, niektóre poważne, które jednak nie górują nad zaletami. Jest to wartościowe studium źródłoznawcze, które jednak we współczesnej dyskusji naukowej osadzone jest dość płytko. Wysoko przychodzi mi ocenić poszczególne podrozdziały, zwłaszcza te, w których omawiane są narracje bliskie Kościołowi i duchownym - często wnikliwe, solidnie osadzone w materiale źródłowym. Nieco gorzej odbieram syntetyczny aspekt publikacji. Nietrafne, moim zdaniem, założenia metodologiczne sprawiły, że książka to raczej suma podrozdziałów niż spójna, jednolita narra-

22 C. Schindler, Per carmina laudes. Untersuchungen zur spätantiken Verspanegyrik von Claudian bis Coripp, Berlin - New York 2009.

${ }^{23}$ Romans, Barbarians, and the Transformation of the Roman World. Cultural Interaction and the Creation of Identity in Late Antiquity, red. R.W. Mathisen and D. Shanzer, Farnham-Burlington 2011.

${ }^{24}$ Kingdoms of the Empire. The Integration of Barbarians in Late Antiquity, red. W. Pohl, Leiden-New York-Köln 1997.

${ }^{25}$ W. Pohl, Perceptions of Barbarian Violence, [w:] Violence in Late Antiquity. Perceptions and Practices, red. H.A. Drake, Aldershot-Burlington VT 2006. 
cja. Obraz barbarzyńcy, który może zbudować w swej głowie czytelnik po zakończeniu lektury, jest bogaty, ale nieco chaotyczny. Pragnę jednak podkreślić, że powyższe krytyczne komentarze w żadnym razie nie dyskredytują omawianej publikacji. Jej ukazanie się na rynku wydawniczym wzbogaca polską dyskusję naukową na temat epoki późnej starożytności ogólnie, a tematyki interakcji pomiędzy Rzymianami a barbarzyńcami w szczególności. Mam nadzieję, że wszelkie poczynione uwagi pozwolą autorowi udoskonalić ewentualne drugie wydanie bądź zagraniczne tłumaczenie swojego studium.

Adrian Szopa (Kraków) ORCID: 0000-0001-7735-7145 